\title{
Production of Third-Person Singular $-s$ And be Copula in Communication Tasks by Vietnamese EFL Learners: Acquisition Order and Learner Orientation to Form
}

\author{
Bao Trang Thi Nguyen \\ University of Foreign Languages, Hue University \\ Jonathan Newton \\ Victoria University of Wellington
}

\begin{abstract}
Research on the acquisition order of inflectional morphemes in English has shown that thirdperson singular $-S(3 \mathrm{SG}-S)$ is challenging to acquire and acquired later than be copula by both L1 and L2 learners of English. In a departure from the usual practice of controlled elicitation, the current study investigated the production of these two forms by Vietnamese EFL learners in oral communication tasks performed in intact classrooms. Vietnamese L1 does not inflectionally mark $3 \mathrm{SG}-S$ although the construction of be copula in Vietnamese and English shares some features. These differences motivated the selection of the two target forms. Nine pairs of Vietnamese EFL university students were recorded performing five communicative tasks generated contexts for use of $3 \mathrm{SG}-s$. over three weeks in their normal classes. Performance data were transcribed and analyzed for frequencies of production and omission of the two target forms in obligatory contexts. After completing the tasks, the students were interviewed about what they attended to when performing the tasks. Interview transcripts were analyzed thematically. Results show that the learners omitted $3 \mathrm{SG}-S$ in most obligatory contexts and across all tasks. They were better at accurately producing be copula than $3 \mathrm{SG}-s$ but accuracy rates varied between learners. Interview data revealed the conscious decisions learners made concerning the accuracy of their language production. The findings are discussed with reference to different theoretical models. The study advances understanding of acquisition of $3 \mathrm{SG}-S$ and be copula by EFL learners and offers pedagogical implications for how a focus on inflectional forms can be managed in oral communicative task performance.
\end{abstract}

\section{Résumé}

Des recherches sur l'ordre d'acquisition des morphèmes flexionnels en Anglais ont montré que, pour les apprenants L1 et L2, l'acquisition de la marque de la troisième personne du singulier $-s(3 \mathrm{SG}-s)$ est difficile et plus tardive que celle de la copule be. Différemment de la pratique commune des élicitations contrôlées, la présente étude a investigué la production de ces deux formes par des apprenants d'EFL Vietnamiens dans des activités de communication orale dans des salles de classe intactes. Dans le L1 Vietnamien on ne marque pas la flexion $3 \mathrm{SG}-S$, tandis que la construction de la copule be en Vietnamien et en Anglais comportent quelques similarités. Ces différences ont motivé la sélection de ces deux formes. Neuf paires d'apprenants universitaires Vietnamiens d'EFL ont été enregistrées, au long de trois semaines de leurs cours réguliers, lors de leur participation à 
cinq tâches communicatives engendrant des contextes pour l'usage de 3SG-s. Les données de performance ont été transcrites et analysées en fonction des fréquences de la production et omission des deux formes cibles dans des contextes obligatoires. Les étudiants ont aussi été interviewés afin d'examiner à quoi ils faisaient attention lors de l'exécution de l'activité. Les transcriptions des entretiens ont été analysées par thème. Les résultats ont montré que les apprenants ont omis le $3 \mathrm{SG}-S$ dans la majorité des contextes obligatoires. Les apprenants ont été plus précis dans l'utilisation de la copule be, mais le degré de précision a varié selon l'apprenant. Les données de l'entretien ont révélé les décisions conscientes des étudiants concernant l'exactitude de leur production langagière. Cette étude fait avancer les connaissances sur l'acquisition du $3 \mathrm{SG}-s$ et de la copule be par les apprenants d'EFL et fournit des consignes pédagogiques sur comment l'attention sur les formes flexionnelles peut être gérée lors de l'exécution de tâches de communication orale.

\section{Production of Third-Person Singular $-s$ And be Copula in Communication Tasks by Vietnamese EFL Learners: Acquisition Order and Learner Orientation to Form}

\section{Introduction}

Third-person singular in the present tense in English is inflectionally marked as $-s$ (henceforth $3 \mathrm{SG}-s$ ) to indicate agreement in person and number (e.g., I walk, he walks). First language (L1) studies on inflectional acquisition (e.g., Brown, 1973) show that 3SG-s is the second to last morpheme to be acquired, well after be copula and before auxiliary $b e$. Research on the order of English morpheme acquisition by second language (L2) learners also shows $3 \mathrm{SG}-s$ to be late acquired, coming second to last before possessive $-s$ and after be copula (Dulay \& Burt, 1974; Freeman, 1975; Goldschneider \& DeKeyser, 2001; Krashen, 1982). This paper investigates whether this acquisitional order applies to Vietnamese learners of English as a Foreign Language (EFL). Vietnamese is an isolating language, and as such, does not mark subject-verb-agreement (Ngo, 2001) or use affixal inflection of the lexical verb to indicate the third person singular present tense. In the following examples, the same verb form 'đọc' is used for all the subjects, plural or singular, while in English the inflected form- $s$ is obligatory to mark subject-verb agreement in $3 \mathrm{SG}-S$.

1.Tôi đọc. [I read.]

2. Cô/Anh ấy đọc. [She/He reads.]

3. Họ đọc. [They read.]

4. Bạn đọc [You read.]

5. Chúng tôi đọc. [We read.]

The Morphological Congruency Hypothesis (Jiang et al., 2014) posits that a meaning that is not realized morphologically in a learner's L1 will be difficult to acquire in an L2. The total absence of any L1 equivalent of the 3SG-s morpheme in Vietnamese is likely to make its acquisition particularly challenging. In contrast, be copula in Vietnamese shares some similarities with English. When the subject complement is a noun phrase (examples 1a-1b), "là" in Vietnamese is equivalent to " $i s$ " in English. However, be copula is absent when the subject complement is an adjective, as in examples $2 \mathrm{a}-2 \mathrm{~b}$, where it also functions as a stative verb (Dam, 2006). 
1a. Cô ấy/Anh ấy là một giáo viên tuyệt vời. [She/He is a great teacher.]

1b. Đó là một ngôi nhà đẹp. [That is a nice house.]

2a. Cô ấy/Anh ấy rất tử tế. [She/He is very kind.]

She/He very kind.

2b. Cặp của tôi nặng. [My bag is heavy.]

My bag heavy.

The similarity between Vietnamese and English regarding be copula is likely to make it easier to acquire than $3 \mathrm{SG}-S$. It is therefore hypothesized that be copula will be acquired first for Vietnamese EFL learners. While this order of acquisition has been found for English L1 and L2 learners, the research is typically conducted experimentally and in English as a second language (ESL) contexts in which there is wide exposure to English outside the classroom. The present study sought to complement this research by drawing on naturally occurring classroom interaction between EFL learners doing communication tasks. These tasks represent one of the few opportunities the learners have to interact in English. The study also drew on learner self-report data to investigate learner perspectives on the use of $3 \mathrm{SG}-S$ and be copula. Few studies of this kind have used learner self-report data on production or omission of inflectional forms in oral communication. These data offer potentially valuable insights into the factors that influence whether learners are aware of or attend to such forms. These insights have the potential to inform the use of communication tasks in EFL contexts.

\section{Literature Review}

\section{Theoretical Perspectives on the Acquisition of 3SG-s in L1 and L2 English}

Research has shown that both young L1 children and L2 learners frequently omit $3 \mathrm{SG}-S$ in obligatory contexts (e.g., Brown, 1973; Burt \& Dulay, 1974; Ionin \& Wexler, 2002; Kelly, 2017; Krashen, 1982; Siemund \& Lechner, 2015). Different hypotheses have been proposed to account for this phenomenon. L1 research draws mainly on the Optional Infinitive (OI) or Root Infinitive Stage hypothesis (Rice \& Wexler, 1996; Wexler, 1994) which claims that children opt for the infinitive form instead of finite forms that mark agreement because they treat tense/agreement as optional (Leonard, et al., 2015, p.2). For young L2 learners, this optionality is attributed to "an impairment of functional categories and/or features in L2 grammar" (Ionin \& Wexler, 2002, p. 99) due to maturational constraints. The OI is therefore argued to present an acquisitional phase that child learners go through, with finite forms eventually appearing when no longer inhibited by these 'maturation' constraints (see Kelly, 2017). For L2 learners no such constraints exist and so an alternative explanation of the use of nonfinite forms in finite contexts is needed.

An alternative morphosyntactically-oriented theoretical perspective called the Missing Surface Inflection Hypothesis (MSIH) challenges the OI hypothesis. It argues that the difficulties L2 learners experience with $3 \mathrm{SG}-S$ are due to the problem of mapping the abstract representation of the given morphological inflection to use (Ionin \& Wexler, 2002; Lardiere, 2000; Prévost \& White, 2000). Research that supports this claim has shown that learners with a range of L1s use non-finite forms in obligatory finite contexts, but rarely use finite forms in non-finite environments (Ionin \& Wexler, 2002; Lardiere, 2000; Prévost 
$\&$ White, 2000). The rare occurrence of finite forms in non-obligatory contexts shows that the requisite functional categories are indeed present in the $\mathrm{L} 2$ grammar of the learners, but that they have difficulty mapping abstract features onto surface forms (Prévost \& White, 2000 , p. 127). This mapping difficulty is hypothesized to cause L2 learners to prefer using non-finite forms of verbs, especially under the pressure of communication (Prévost \& White, 2000). The low communication value of $3 \mathrm{SG}-s$ is a factor that contributes to this mapping issue (Goldschneider \& DeKeyser, 2001).

Other explanatory accounts such as the Morphological Congruency Hypothesis (Jiang et al., 2014) emphasize the role of the L1, pointing to the tendency for L2 learners whose L1s are inflected languages to use inflected forms more accurately than learners whose L1s are null in inflection or are isolating languages (Blom, et al., 2012; Hsieh, 2009). As Ellis and Sagarra (2010) show in two studies involving L1 English speakers learning Latin and L1 Chinese speakers learning English, learners from L1s that do not have morphemes that are congruent with the L2 tend to 'block' attention to them. As Blom et al. (2012, p.26) argue, "in the case of isolating L1s, verbs would lack associations with features like person and number. As a result, children with isolating L1s might not initially attend to, or perceive, 3SG-s in English". Empirical support for this claim is provided by Paradis (2011), who found that L1 Chinese learners of English (an isolating language) produced $3 \mathrm{SG}-S$ less accurately or less consistently than speakers of L1s such as Hindi, Punjabi, Urdu, Spanish, and Arabic that have a closer match with regards to the mental representation of the morphological inflection. Further evidence is provided by Blom et al. (2012) who analyzed the oral production data from 15 L2 English child learners from different L1 backgrounds in Canada. Twelve of these learners recently migrated to Canada and three were Canada-born. In this longitudinal study, spontaneous speech samples of playtime conversations between children and the researchers were collected every six months over a two-year period. Multiple factors were shown to influence production of 3SG-s, including L1, input, and the stage of the learners' lexicogrammar. The authors conclude that learners with an inflected L1 background are more likely to perform better on $3 \mathrm{SG}-S$ than those without. As a corollary, they argue that children from an isolating L1 background "need more time to generalize over allomorphs that express the same semantic categories, namely $3 \mathrm{SG}-S$ and are more sensitive to phonological detail in the input than inflecting L1 children" (Blom et al., 2012, p. 26).

The input-processing perspective or the Network model (Blom et al., 2012; Bybee, 2010) explains the acquisition of $3 \mathrm{SG}-S$ as a factor of the frequency of verbs appearing in the input that learners receive. For example, learners are more likely to produce a highfrequency verb such as 'walks' with its inflectional marking than lower frequency verbs such as 'wishes'. Similarly, the frequency of the different allomorphs of $3 \mathrm{SG}-s(/ \mathrm{s} /, / \mathrm{z} /$, /iz/) influences learner production of 3SG-S. As Blom et al. (2012) found, the higher frequency of the $3 \mathrm{SG}-S$ allomorph $/ \mathrm{z} /$ resulted in it being produced more consistently than either the lower frequency /s/ and /iz/ frequency. Similarly, /s/ is produced less accurately than $/ z /$, again due to its lower frequency in the input.

Finally, a phonological perspective (Levelt et al., 2000; Song et al., 2009) focuses on articulation of a given morpheme and its allomorphs and predicts that thematic verbs that end with a vowel sound (singletons/simple codas) are more likely to get their inflectional form pronounced than complex codas. Thus, single codas such as 'plays/sees' are acquired earlier than cluster codas (e.g., 'looks/needs/opens') (Levelt, et al. 2000). Song, et al. (2009) confirmed this in a longitudinal study involving English L1 children 
under 6 years of age whose production of $3 \mathrm{SG}-S$ was more accurate in simple rather than complex codas.

\section{Acquisition of 3SG-s and be Copula}

Most studies on $3 \mathrm{SG}-S$ have treated it as an affixal inflection exclusive of be copula suppletive inflection (Ionin \& Wexler, 2002) although some studies have shown that be copula is acquired before 3SG-S (e.g., Zobl \& Liceras, 1994). Lardiere (1999) studied one L1 Chinese learner of English, Patty, who failed to produce almost all the affixal inflected forms $-s$ but used many be copula forms with appropriate inflection. Jia and Fuse (2007) also found that L1 Chinese immigrant learners of English in the US, aged from 5 to 16, dropped the $3 \mathrm{SG}-S$ morpheme about $90 \%$ of the time while the rate of omission of be copula was much lower (about 60\%). Similar results were found in Ionin and Wexler's (2002) research with Russian L1 child learners of English in the US aged from 4 to 14 who acquired be copula before $3 \mathrm{SG}-S$ in the present tense.

In contrast to research in ESL contexts, EFL studies are limited and focus on the production of $3 \mathrm{SG}-S$ in writing tasks. Wee et al. (2010) found that $3 \mathrm{SG}-s$ was frequently omitted by Malaysian EFL students in academic writing and similarly, Muftah and RafikGalea (2013) found the same for Arabic EFL undergraduate students, with data also collected from grammaticality judgement tasks. In oral task data, Urano (2008) found that omission and oversuppliance of $3 \mathrm{SG}-S$ were the two most common errors made by Japanese EFL learners, with marking of singular and plural present tense on lexical verbs also problematic. Hsieh (2009), investigated how twenty 11-14 year- old L1 Chinese EFL learners produced $3 \mathrm{SG}-S$, past tense morpheme- $-e d$ and be copula. He collected speech samples through interviews and story-telling tasks at home or in school environments and found fewer errors with be copula than omission of $3 \mathrm{SG}-s$. The learners in Hsieh's study omitted $3 \mathrm{SG}-S 78 \%$ of the time, a finding he explained was due to the difficulty mapping the form to the intended meaning under communication pressure. Helland and Alvarez (2007) conducted a longitudinal study of five bilingual Catalan and Spanish child learners of English in schools in Barcelona using narrative and interview tasks to elicit 3SG-S. They found that the learners used root infinitives or omitted $3 \mathrm{SG}-S$ in most obligatory contexts, a finding they partially attributed to the interaction of the L1 and L2 grammars (Helland \& Alvarez, 2007, p.2).

\section{Acquisition of 3SG-s/be Copula by Vietnamese L1 Learners of English}

To our knowledge, two studies to date have documented the production of $3 \mathrm{SG}-S$ by Vietnamese L1 learners of English. In both, the learners were migrants to other countries. McDonald (2000) found that Vietnamese L1 learners of English in the US had more difficulty with $3 \mathrm{SG}-s$ than their Spanish L1 counterparts, even though both groups were exposed to English during their childhood. McDonald explains this finding with reference to the rich inflectional character of Spanish in contrast to Vietnamese, an inflection-free language. Siemund and Lechner (2015) interviewed 160 bilingual 12-16year-old learners of English in Hamburg, Germany, including Russian-German, TurkishGerman, and Vietnamese-German learners. The data were compared with a control group of monolingual speakers. The findings show that Vietnamese L1 immigrant learners had more problems with the verb-subject agreement than Russian and Turkish L1 background 
learners. This finding was attributed to the influence of L1, and notably to the characterization of Vietnamese as an isolating language.

No studies have examined how Vietnamese EFL learners living in Vietnam, an environment where English is rarely used outside of the EFL classroom, produce $3 \mathrm{SG}-S$, and do so in comparison to their production of be copula. Neither has research on these constructions incorporated a learner perspective, although previous research has sought learners' perceptions of how they acquired other target forms. Collins (2005), for example, used retrospective post-task interviews to ask Chinese and Japanese L1 adult learners of English to reflect on their use of the past tense and aspect in controlled written task performances. Li and Gao (2017) employed verbal reports to understand how Chinese learners of English performed requests in English, and Rogers et al. (2016) used self-report data to understand learners' use of case-marking inflection. These studies show how data from retrospective interviews can provide useful insights into the role of attention and awareness on the learners' behaviors.

Accordingly, we were interested in the learners' accounts of whether they were consciously aware of the extent to which they were producing the target forms accurately, and if they were, what deliberate choices and processes they made and why. In interpreting this data, we drew on the limited attention capacity model proposed by Skehan (2015). This model provides a cognitivist account of how communicative pressure may force the learner to make trade-offs in how they allocate their limited attentional resources to the complexity, accuracy and/or fluency of their language production. We also drew on a skill acquisition theory account of three learning processes that underpin skilled performance: forming declarative knowledge, proceduralizing routines, and automatizing these routines (DeKeyser, 2014).

The research addresses two research questions:

1. How accurately do Vietnamese EFL learners use $3 \mathrm{SG}-S$ and be copula in their communication task performance?

2. What do learners' self-reports reveal about their production of these constructions?

Based on L2 research on inflection (e.g., Ionin \& Wexler, 2002) and the ways 3SG$s$ and $b e$ copula function in Vietnamese and English, two hypotheses relevant to Research question 1 were formed:

Hypothesis 1: That because Vietnamese L1, as an isolating language, does not support the use of inflectional morphemes, Vietnamese EFL learners will omit a majority of $3 \mathrm{SG}-s$ in their oral task production.

Hypothesis 2: Because Vietnamese uses be copula in the same way as English with noun phrase complements, the production of $b e$ copula will be more consistent and accurate than the production of $3 \mathrm{SG}-s$.

For Research Question 2, ten learners were interviewed after they had performed the oral tasks and asked to reflect on what they attended to while carrying out the tasks. The qualitative analysis of this self-report data does not warrant a hypothesis. 


\section{Methodology}

\section{Participants}

Eighteen first-year English major students from an EFL speaking class volunteered to participate in the study. They were in the second semester of their first year at a university of foreign languages in Vietnam. All but one of them were female, and all were 19 years of age. Their scores on a pre-course test ${ }^{1}$ placed them at basic user (A2) to independent user (B2) on the Common European Framework of Reference (CEFR). They would all have had explicit instruction on 3SG-S and be copula in school from age 11-18. Outside of the classrooms, they have had limited exposure to English, although some reported watching English movies and three worked part-time selling food and souvenirs on a street popular with tourists.

\section{The Communication Tasks}

The majority of studies to date on morpheme acquisition elicit spontaneous speech data by means of interviews conducted with a researcher (e.g., Blom et al., 2012; Hsieh, 2009; Ionin \& Wexler, 2002; Siemund \& Lechner, 2015; Song et al., 2009). The present study employed pedagogical tasks performed by the learners during their normal classroom lessons to strengthen the ecological validity of the research. Five communication tasks were used in the study, all of which required students to talk about the daily habitual activities of another person, and therefore required the use of $3 \mathrm{SG}-S$. In this sense, they were akin to what Ellis (2003) describes as focused tasks, defined as communication tasks that require the use of specific grammatical features, although there was no pre-teaching or mention of these features ( $3 \mathrm{SG}-S$ and be copula) prior to or after the task performances. The tasks all contain the essential task features proposed by Ellis and Shintani (2013), namely (a) a primary focus on meaning, (b) an information gap, (c) learners using their own linguistic resources to complete the task, and (d) a communicative outcome other than the display of language. The tasks fit Duff's (1986) classification of divergent tasks in that they did not require learners to agree on a non-linguistic outcome. The tasks were designed to fit naturally into the flow of the lessons, and so students performed the tasks in their normal classes over a three-week period as follows:

\section{Week 1}

Task 1: Talk about the daily job of a person you know.

Task 2: Talk about a person you adore and state the reasons why. Week 2

Task 3: Talk about who your everyday hero is and why. Week 3

Task 4: Talk about what one of your best friends often does in his or her free time. Task 5: Interview a friend and ask about what they do to improve their English.

(See Appendix for the tasks) 


\section{Task Implementation Procedures}

In the week prior to data collection, students performed a pilot task and familiarized themselves with self-recording using their smartphones. The main tasks were all carried out in scheduled speaking class lessons. Students were first allowed 10 minutes of unguided planning time. It was observed that students used the planning time to prepare content for their talk in the form of short notes. They then took turns to talk to each other about the task topic, audio-recording themselves using their smartphones. Each member of a pair was designated two or three of the five tasks for which they were required to speak first. They sent the audio files to the researcher through email immediately after a task was completed.

Students were not informed of the focus of the study (3SG-S and be copula) and appeared to behave as they did in their usual lessons, for example, by chatting freely and teasing each other in a friendly manner during the tasks. All students performed the five tasks with ease. Following the final task, 10 volunteer students were interviewed to obtain their perspective on (a) what they paid attention to when performing the tasks and in their general communication in English (see Section 3.4 below) and (b) whether and how they attended to the use of $3 \mathrm{SG}-S$ and be copula during the communication tasks. Interviews were either conducted on the same day as the final task or, in some cases, a few days later due to logistical constraints. Four weeks later, after preliminary analysis of the task performance data, the students were asked follow-up questions.

\section{Data Set}

Task performances were collected over a three-week period. Most of the students performed three to four of the five tasks, although five of them performed all five tasks and five performed only one task. These gaps were the result of factors such as technical faults, absentees, or students forgetting to record themselves. The task data were transcribed in their entirety. In total there were 54 transcripts from 18 students, making a total of 80.82 minutes of transcribed data. There was considerable variation in length of task performances ranging from 0.35 mins to $3.21 \mathrm{mins}(\mathrm{M}=1.5 \mathrm{mins}, \mathrm{SD}=0.72)$. For the interviews, five students chose to respond through email and five through face-to-face interviews (one group of two students and one of three). Interviews were audio-recorded with the students' consent. They lasted about 40 minutes and were conducted in Vietnamese so that students were able to express themselves with ease.

\section{Data Analysis}

The focus on students' use of $3 \mathrm{SG}-S$ in declarative sentences meant that negative and interrogative sentences were excluded. The analysis of the oral production data was based on Ionin and Wexler's (2002) framework of analysis. The use of regular 3SG-S was analyzed in two main categories: Omission and use (correct and incorrect) in obligatory contexts. Additional analysis was conducted on the production of $-s$ in be copula in its present singular form (is) to allow comparison between the two forms.

Data analysis was first conducted for each student per task, then for all tasks, and then aggregated to calculate the total omissions and errors in the production of $3 \mathrm{SG}-S$ and be copula. The number of omissions of $3 \mathrm{SG}-S$ was calculated separately in relation to the obligatory contexts identified in the transcripts. Examples of the use of different categories 
from the dataset are given along with student codes $(S 1, S 2, S 3$, etc.) and task codes (Job, Free time, English, etc.) in brackets.

In the data, some verbs were re-used, though with different collocates. These verbs were counted and included in the analysis since the use of certain verbs even by the same person might be variable (Brown, 1973). As in previous research (Ionin \& Wexler, 2002), utterances that were not intelligible were excluded. For false starts, only the correct forms were counted. In the example below, only the self-corrected form 'watches' was counted. There were only six instances of self-correction involving the targeted forms.

(a) She often watch... watches videos about English lessons on the internet. (S2, English)

\section{Omission of 3SG-S}

Omission was identified where students did not produce the $3 \mathrm{SG}-S$ morpheme in obligatory contexts (Ionin \& Wexler, 2002, p. 105), as in the following example:

(b) My uncle often clean the road around my village. (S11, hero)

Various forms or allomorphs of $3 \mathrm{SG}-\mathrm{s}$ were also identified and categorized according to their pronunciation: /s/, /z/, and /iz/ (Fromkin \& Rodman, 1998). Lexical verbs that end with sibilant consonants such as $/ \mathrm{s} /, / \mathrm{z} /, / \mathrm{t} /, / \mathrm{J} /$, and $\mathrm{d} z /$ would normally have their $3 \mathrm{SG}-S$ morpheme pronounced as $/ \mathrm{iz} /$. For those verbs that end with voiced consonants, namely /b/, /d/, /g/, /1/, /m/,/n/, /y//v/, and /ð/, and all vowel sounds, 3SG-S would normally be pronounced as $/ \mathrm{z} /$. $3 \mathrm{SG}-S$ should be produced as $/ \mathrm{s} /$ after all voiceless consonants such as $/ \mathrm{p} /, / \mathrm{k} /, / \mathrm{f} /, / \mathrm{t} /$, and $/ \theta /$. The following examples (c), (e), and (g) are of $3 \mathrm{SG}-S$ 'produced' for each of the three allomorphs of $3 \mathrm{SG}-S$, while the remaining examples (d), (f), and (h) are of it omitted.

/iz/ (c) He finishes work at about 7pm every day. (S4, Job)

(d) My friend practice by listening to English news. (S14, English)

/z/ (e) Every time when I have problems ... she always knows the answers. (S18, hero)

(f) Every day he travel to work by bike because his company is not too far. (S4, job)

/s/ (g) Every day it takes her 20 minutes to go to the office. (S8, Job)

(h) She want to help my brother to study. (S9, Job)

\section{Substitution of 3SG- $s$}

Substitution of $3 \mathrm{SG}-S$ was coded using a data-driven process of open coding. This allowed for the coding of instances of inappropriate substitution of $3 \mathrm{SG}-S$ with nonstandard forms in contexts where $3 \mathrm{SG}-S$ was obligatory. Four types of inappropriate substitution were identified. The first was use of the present participle:

(i) My mother cooking every day. (S18, free time)

(j) He working hard every day. (S13, English) 
The other three were, respectively, use of the simple future tense, the simple past, and would + verb, as illustrated in (k), (l) and (m). There were no instances of 3SG-s used with any subject other than third-person singular.

(k) He will travel to another city two or three day, even a week per month. (S15, Job)

(1) She design posters advertising for English centers in HCM city and her boss gave her five to ten poster per week. (S13, Job)

(m) Sometimes Lan would go out to practice English with foreigners. (S12, English)

\section{Be Copula}

In the data, be copula was used in three ways:

1. be copula 'is' used (present) in obligatory contexts

(n) Her life is busy. (S10. Job)

2. $-S$ in be copula 'is' was either produced (o) or not produced (p).

(o) My hero is /iz/ my mother. (S13, hero)

(p) She is $/ \mathrm{i} / \mathrm{a}$ teacher. (S1, job)

3. Absence of be copula

The be copula is not used at all in obligatory contexts as in examples (q), (r) and (s):

(q) My father very tired when coming home. (S16, Job)

(r) My house always tidy. (S7, Job)

(s) He a smart student. (S3, English)

There were no instances of 'is' (be copula) used for plural subjects, and nor were there any other variations. In other words, once the $-s$ in be copula was produced it was produced correctly all the time.

\section{Inter-Coder Reliability}

Inter-coder reliability was checked in two ways. First, re-transcription was independently carried out for $10 \%$ of the data samples by a second EFL lecturer. Reliability was measured by the percentage of words transcribed identically by the two raters. An agreement percentage of $87 \%$ was achieved, which is considered satisfactory. All the disagreements were resolved through discussion between the two coders.

Second, another proficient EFL teacher was trained and then coded randomly $15 \%$ of the transcripts for the identification of all the dependent variables. Percentage agreement was used to calculate the inter-coder reliability for each category and the results show satisfactory reliability from $83.3 \%$ to $100 \%$ (see Table 1 ). According to Miles and Huberman (1994), agreement between the two codes should be from $80 \%$ of the time. All the disagreements were resolved through discussion between the two coders. 
Table 1

Inter-coder Reliability Results

\begin{tabular}{lc}
\hline Code & \% agreement \\
\hline $3 \mathrm{SG}-S$ in obligatory contexts & $100 \%$ \\
\hline Inappropriate use of $3 \mathrm{SG}-S$ & $86 \%$ \\
\hline Omission of $3 \mathrm{SG}-S$ & $85.7 \%$ \\
\hline$B e$ copula obligatory contexts & $100 \%$ \\
\hline Inappropriate use of $3 \mathrm{SG}-S$ & $85.7 \%$ \\
\hline Omission of $-S$ in $b e$ copula & $88.9 \%$ \\
\hline Absence of use of $b e$ copula & $87.5 \%$ \\
\hline
\end{tabular}

\section{Interview Data}

The interviews were transcribed verbatim and the transcripts were then subject to thematic analysis in the original language of Vietnamese. Analysis in the language of the interview helps retain the intended meanings by participants (Casanave, 2010). The analysis involved an iterative process of reading and re-reading each of the interview transcripts to understand what students said about their allocation of attention to the target forms while carrying out the tasks. As themes such as fluency focus or social alignment were identified, they were coded and treated as "provisional knowledge" (Silverman, 2010, p. 279) that awaited confirmation. Themes for each transcript were entered into an Excel spreadsheet to keep track of the codes, with new codes/themes added as the analyses continued. This allowed for tracing the number of occurrences of a theme and the focus of the themes by each and all the participants. This process addresses Bryman's (2008) concern that in theme-based analysis researchers might impose "prevalence" in their subjectivity. In reporting the analysis of the interviews in this paper, excerpts are presented in English only and translations were double-checked by a Vietnamese EFL teacher for accuracy. While researchers such as Yin (2011) argue for presenting excerpts in both original and translated versions for the reader to interpret the data themselves, space constraints prevented this. Pseudonyms were used.

\section{Results}

\section{Use of 3SG $-s$}

A total of 393 obligatory contexts where $3 \mathrm{SG}-S$ would normally be used were identified. There were 46 instances $(11.7 \%)$ of inappropriate use of alternative forms, including present participles (27 instances), future tense forms (10 instances), past tense forms (6 instances) and would + verb combinations (3 instances). As shown in Table 2, of the 347 remaining obligatory contexts, the learners failed to produce $3 \mathrm{SG}-s 272$ times $(78.4 \%)$. As confirmed by a Chi-square analysis, there were no significant differences between the tasks $\left(\chi^{2}(4)=4.994, p=.288\right)$. The data for each learner across tasks show similar patterns of omission, but since the amount of individual learner data per task is small, further statistical analyses were not feasible. 
Table 2

Occurrences of Inflected and Uninflected Forms of $3 S G-S$

\begin{tabular}{lllll}
\hline Task & Inflected & Uninflected & $\begin{array}{l}\text { Total } \\
\text { obligatory } \\
\text { contexts }\end{array}$ & $\begin{array}{l}\text { \% s } \\
\text { uninflected }\end{array}$ \\
\hline 1. Job & 22 & 62 & 84 & 73.8 \\
\hline 2. Idol & 3 & 17 & 20 & 85.0 \\
\hline 3. Hero & 9 & 39 & 48 & 81.3 \\
\hline 4. Free time & 18 & 58 & 76 & 76.4 \\
\hline 5. English & 23 & 96 & 119 & 80.7 \\
\hline Total & 75 & 272 & 347 & 78.4 \\
\hline
\end{tabular}

A breakdown of the data for individual students (following Ionin \& Wexler, 2002, p. 107) is presented in Figure 1. Except for two students with the lowest percentage of omission (20-30\%), and one student at 50\%, most of the students omitted $3 \mathrm{SG}-S$ most of the time.

Figure 1

Percentage of omission of $3 S G-S$

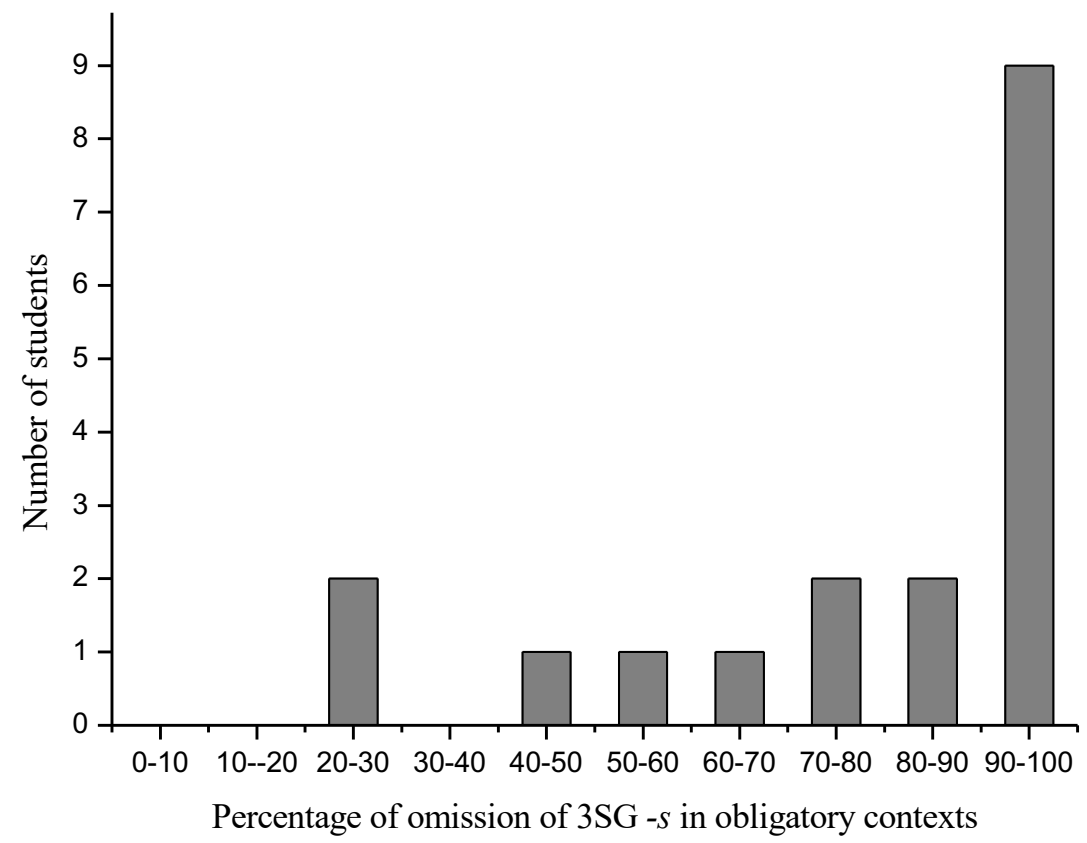

Students' use of 3SG- $S$ was also analyzed according to how they pronounced the three phonetic forms of $3 \mathrm{SG}-s$, namely /z/, /s/ or /iz/. As seen in Table 3 , for all three forms, in most instances in which $3 \mathrm{SG}-S$ should have appeared it was omitted at comparable rates $(84.6 \%, 78.3 \%$ and $76.6 \%$ respectively). Chi-square analysis shows the differences between rates of omission were not statistically significant $\left(\chi^{2}(2)=1.531, p\right.$ $=.465$ ). As shown in Figures 2, 3, and 4, production of the different forms varied considerably among the students. 
Table 3

Production of /iz/, /s/ and /z/

\begin{tabular}{cccc}
\hline $\begin{array}{c}\text { Third-person } \\
\text { singular }\end{array}$ & $\begin{array}{c}\text { Inflected forms } \\
\text { pronounced } \\
\text { correctly } \\
\mathrm{n}(\%)\end{array}$ & $\begin{array}{c}\text { 3SG }-S \text { omitted } \\
\mathrm{n}(\%)\end{array}$ & $\begin{array}{c}\text { Total } \\
\mathrm{N}\end{array}$ \\
\hline $\mathrm{iz} /$ & $8(15.4)$ & $44(84.6)$ & 52 \\
\hline$/ \mathrm{s} /$ & $26(21.7)$ & $94(78.3)$ & 120 \\
\hline$/ \mathrm{z} /$ & $41(23.4)$ & $134(76.6)$ & 175 \\
\hline Total & $75(21.6)$ & $272(78.4)$ & 347 \\
\hline
\end{tabular}

Figure 2

Production of /iz/

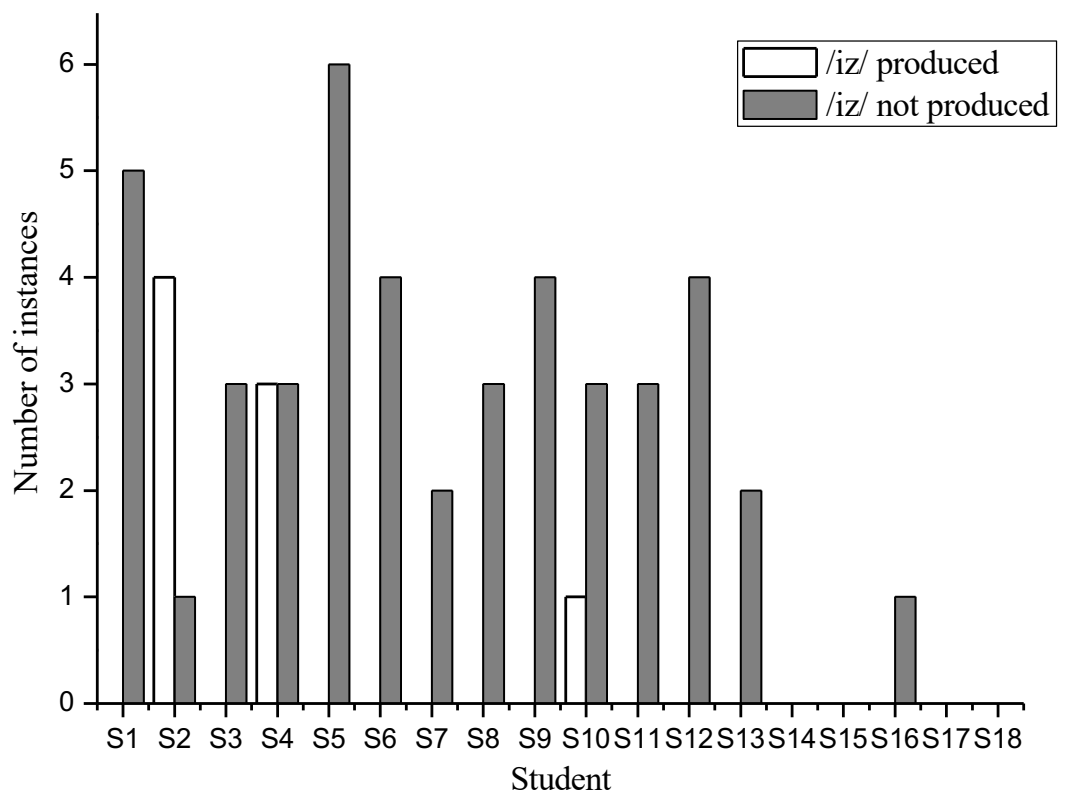


Figure 3

Production of $/ z /$

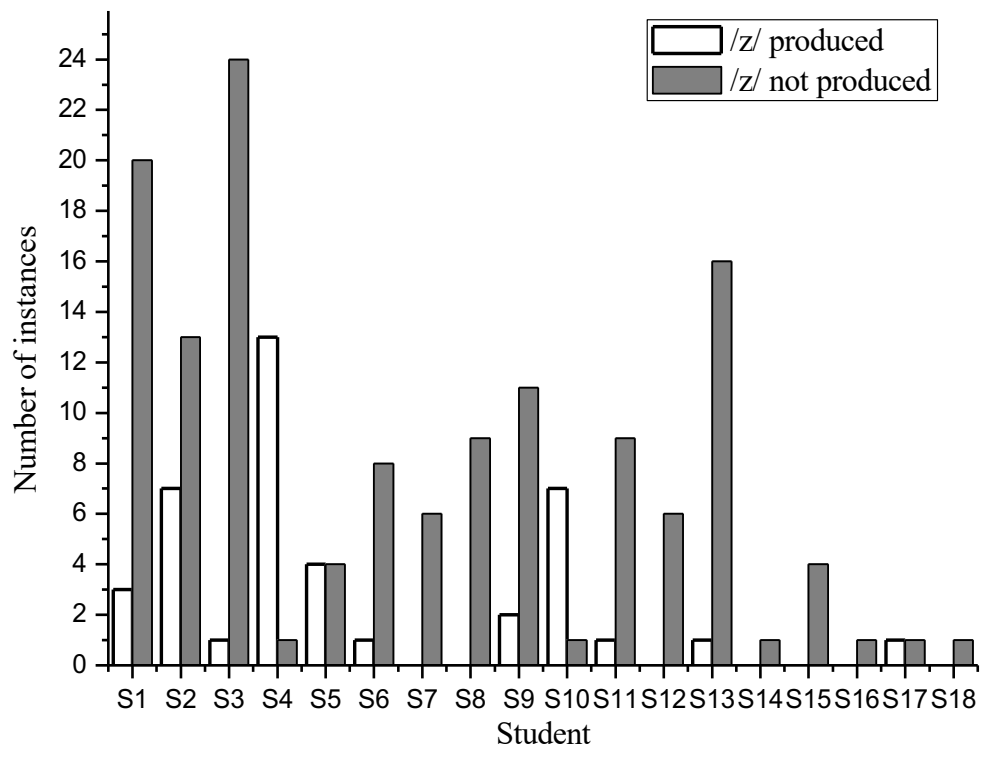

Figure 4

Production of /s/

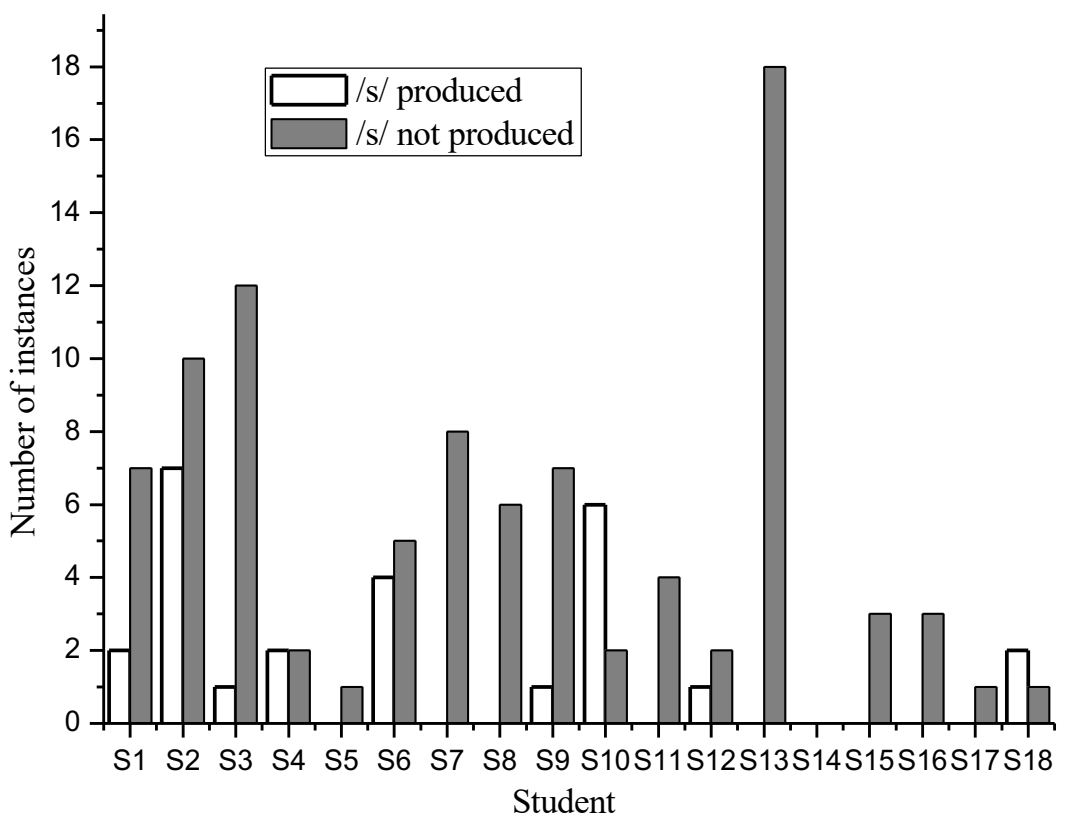




\section{Use of 3SG-s vs. be copula}

The study also tracked how students used be copula in their task performance. The results, as shown in Table 4, show that the students produced the $-s$ in be copula correctly $52 \%$ of the time, did not produce the $-s$ in be copula (e.g., she is /i/ nice) about one-third of the time $(31 \%)$ and omitted be $17 \%$ of the time.

Table 4

Production of be copula in the present third-person singular

\begin{tabular}{cccc}
\hline $\begin{array}{c}\text { \# of obligatory } \\
\text { contexts }\end{array}$ & $\begin{array}{c}\text { Be copula }-S \\
\text { correctly } \\
\mathrm{n}(\%)\end{array}$ & $\begin{array}{c}\text { Be copula }-s \text { not } \\
\text { produced } \\
\mathrm{n}(\%)\end{array}$ & $\begin{array}{c}\text { Be copula not used } \\
\mathrm{n}(\%)\end{array}$ \\
\hline 167 & $87(52)$ & $51(31)$ & $29(17)$ \\
\hline
\end{tabular}

Figures 5 and 6 breakdown these figures by the number of students who failed to produce $-s$ in be copula (Fig. 5) or did not use it at all (Fig. 6). As seen in Figure 5, the production of $-S$ in be copula varied considerably. Despite this variation and in contrast to the trend for very low production of $3 \mathrm{SG}-S$ in Figure 1, eleven of the 18 students produced $-S$ in be copula between $50 \%$ and $100 \%$ of the occasions when it was required. Similarly, in Figure 6, and again in sharp contrast to the omission of $3 \mathrm{SG}-s$, all but one student (17 out of 18) used be copula in the majority of contexts in which it was required, and half of the students produced be copula in almost every obligatory context.

\section{Figure 5}

Percentage of $-\mathrm{s}$ in be copula not produced in obligatory contexts

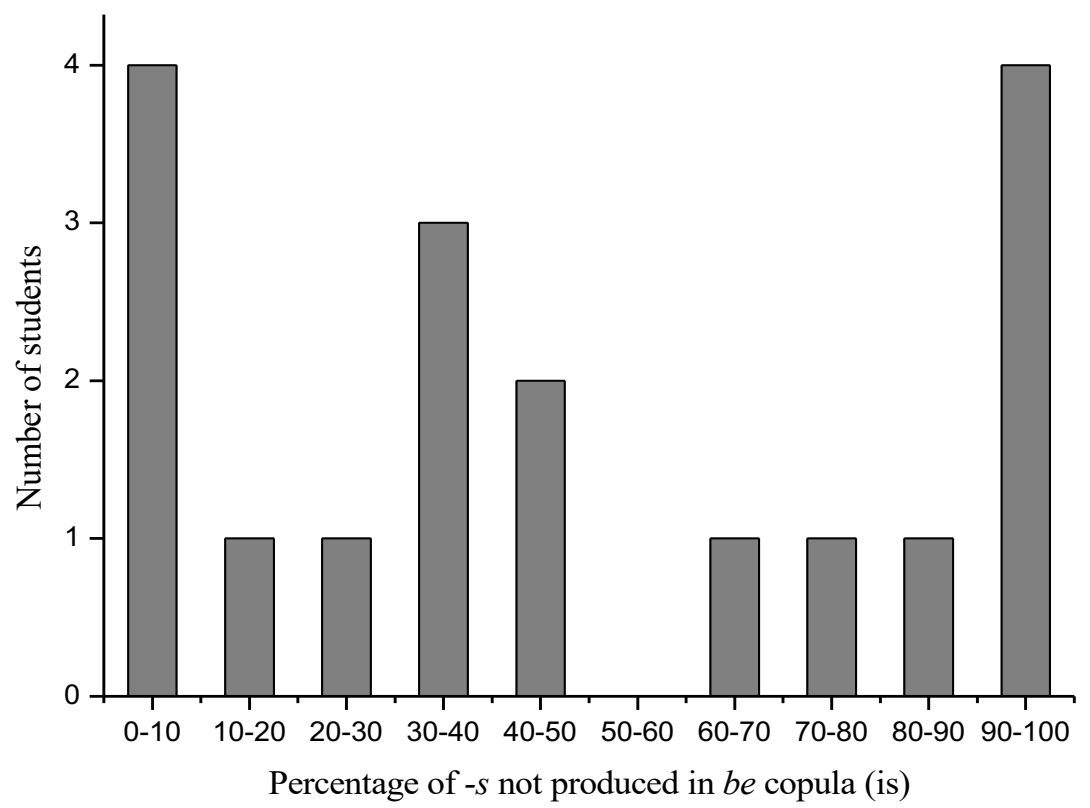




\section{Figure 6}

Absence of use of be copula

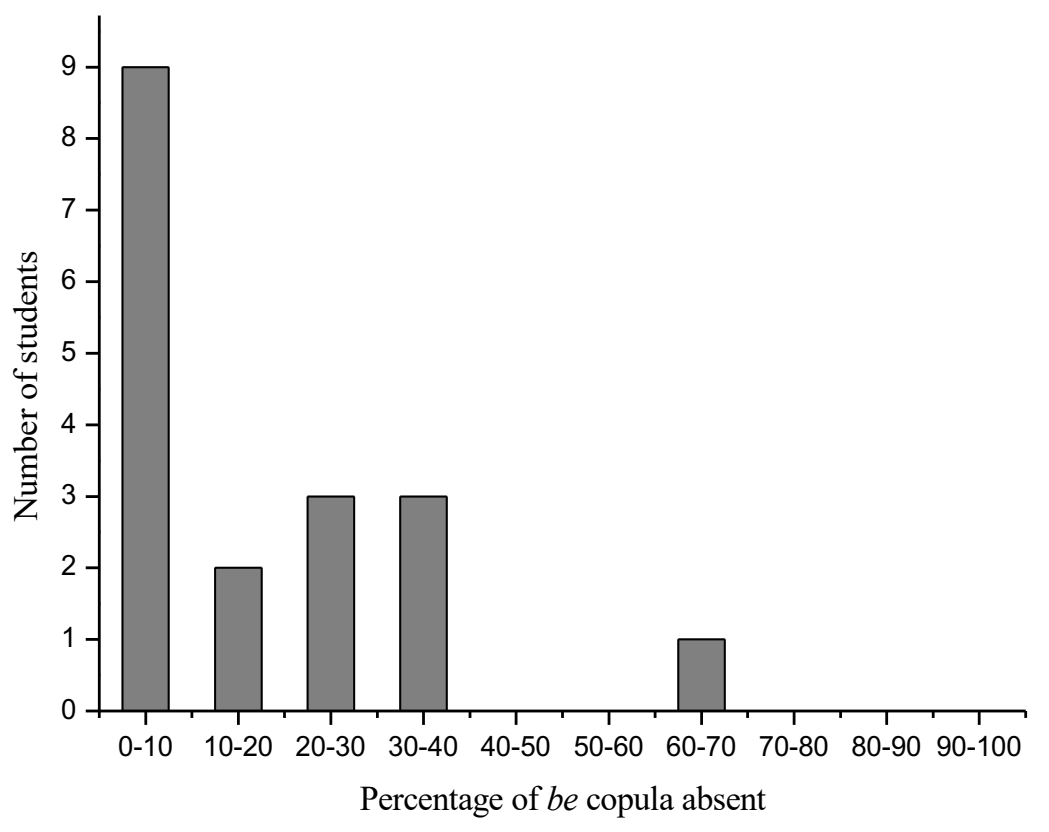

Figure 7 presents the differences between production of $3 \mathrm{SG}-S$ and be copula visually. All the students performed better on be copula, except student S15 who omitted both forms equally $100 \%$ of the time. A Kendall's tau_b correlation test was conducted (due to nonnormality of the data) to explore the relationship between the omission of $3 \mathrm{SG}-S$ and $b e$ copula. No statistically significant correlation was found between omission of $3 \mathrm{SG}-S$ and omission of $-s$ in be copula (is) or between omission of $3 \mathrm{SG}-s$ and absence of use of be copula. $\left(\tau_{\mathrm{b}}=.332, \mathrm{p}=.068\right.$ and $\tau_{\mathrm{b}}=.358, \mathrm{p}=.052$ respectively). The data samples were rather small, so the findings need to be interpreted with care. 
Figure 7

$3 S G-S$ and be copula

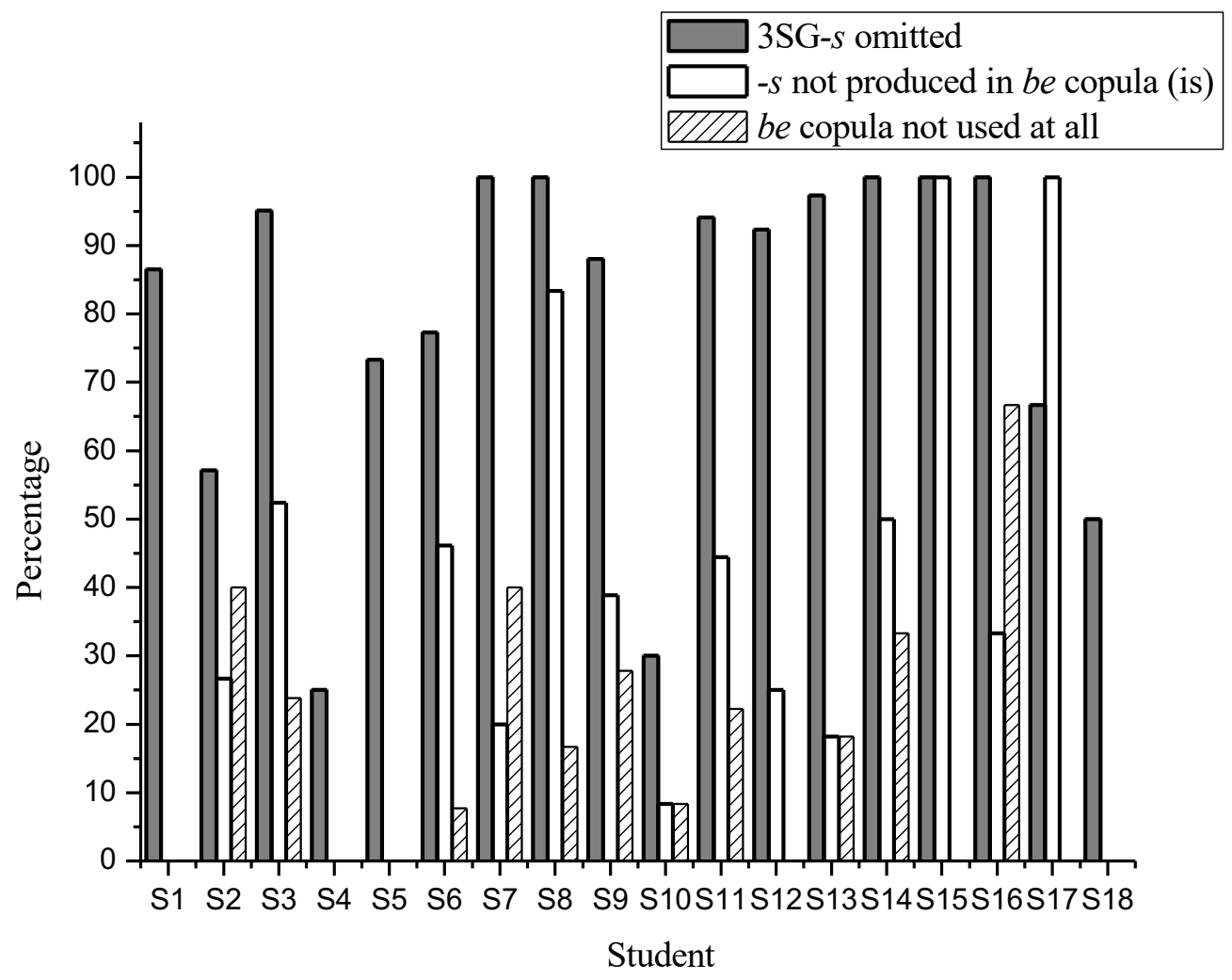

\section{Learners' Insights}

Interviews with students revealed that, not surprisingly, students chose to prioritize communicating their ideas during the tasks and viewed attention to accurately producing inflections such as $3 \mathrm{SG}-S$ as a secondary consideration. As Mai, one of the student participants said:

"Everyone knows that verbs in the present tense with the third person singular needs an 's', but we pay more attention to the meaning of a sentence. When I say 'she works' it takes more time to speak out while I need time for the meaning of the sentence." (Mai) (All interview extracts are translated from Vietnamese.)

For Mai, the articulation of the inflected form is time-consuming and so involves a trade-off with fluency. However, she was one of the three students with the lowest rate of omission $(50 \%$ for $3 \mathrm{SG}-S)$ and her production of be copula was accurate in all task performances.

Another student, Huong, who dropped almost all the $3 \mathrm{SG}-s(97.3 \%)$, was also strongly oriented towards effective communication: 
It is tiring if I have a lot of pauses and interruptions (when I overtly attend to the s) and if I do this often, I'll slow down in communicating my ideas and my interlocutors will just cut through, and not bother to continue with me. They'll say 'ok, fine, ok.' (Huong)

In this comment, Huong shows that she is conscious not just of how attending to $-S$ on word endings, comes at a cost to fluency, but also of how it comes at a social cost. For Huong then, it appears that omission is to some extent a deliberate choice to forgo accuracy for the sake of communicative efficiency. Except 1 shows considerable social alignment in the ways that Mai chimes in with relevant humorous responses to Huong's description of her mother as a superhero.

\section{Excerpt 1:}

Mai: How about you?

Huong: My mother she's a superhero. She can do anything. She manage everything like almost perfect. She wake up early, wake my brother up, do breakfast

Mai: She wake your brother up? Not wake you up? (laugh)

Huong: I'm old enough to erm (laugh with Mai)

... to care about myself. I don't have to depend on her anymore

Mai: Uh (laugh)

Huong: then she go to the market, buy food, get back home ... and have lunch and she only has one hour to sleep.

Mai: $\quad$ One hour is too much!

Huong: No, it's not too much! (laugh)

Mai: $\quad$ My mom has only five minutes to ... to take a nap (laugh)

Huong: I don't know but it's not enough for her... then she work until 7 pm, she can do everything. ... She's a superhero.

(Mai, Huong: Laugh together)

Other students attended to socially align from the very beginning. Excerpt 2 occurred before the two students began the task performance and shows them agreeing to align in how they will perform the talk.

\section{Excerpt 2:}

Minh: $\quad$ E chuẩn bị nói đi. Nhớ nói chơ đừng ậm ừ lâu để nhau chờ mệt nghe. (Hey, get ready to talk. Remember not to pause for so long. Don't ask us each to wait!)

Hoa: $\quad \mathrm{Ok}$, sẽ cố gắng theo. (Will try to stay in tune.)

Minh: Ok. Tau cũng cố. (I'll catch up too.)

Minh/Hoa: laughs

Huong (mentioned earlier) continues with a comment about attention to form during the communication tasks: 
I work at a restaurant for Western tourists, I know that after he, she, it, verbs must have an - s sound, and the like. But in communication, I want to be comfortable. I just communicate without paying much attention to saying the ending sound - s. However, if somebody reminds me, the next turn I'll pay more attention, and in the next sentence I'll attend more, and it'll 'startle' me into it and I come to realize that I have been incorrect before (laugh) (Huong)

Huong is aware of the rules of $3 \mathrm{SG}-S$ or be copula but this awareness does not automatically transfer to accurate use in communication. Mai and Huong's reflections show that they are aware of an attentional trade-off between fluency and accuracy, and they consequently make executive decisions as to how to allocate their attention. However, Huong's comment shows that she also finds it helpful to be reminded about plural form and $3 \mathrm{SG}-S$. As she says, being reminded will "startle" her into realizing that she has let accuracy slip, leading her to attend to it more in future. As DeKeyser (1998) puts it, Huong still needs "declarative crutches" (p.49) to support the procedural use of the target feature.

Huong presents an interesting case. As described above, she omitted almost all $3 \mathrm{SG}-S(97.3 \%)$. However, surprisingly, she was able to naturally link sounds. For example, in one of the task performances, she effortlessly produced "it depends on" with the sound $/ z /$ linked to the subsequent vowel $/ \mathbf{b} /$. When asked about this, she said that it was watching movies and listening to English music on a regular basis that accounts for her natural ability to link sounds. As she explains:

When I first watched movies, I heard /di'pendzwn/ I did not figure out what it was, then I searched and asked my sister, and I came to know that 'ah it is the linking of $/ z /$ and $/ \mathrm{p} /$. Since then once occasions arise, I just say /dı'pendzpn/ and it has now become a habit! (Huong)

Comments by Cuc, who had the second-lowest rate of omission of $30 \%$ of the obligatory contexts of $3 \mathrm{SG}-s$, reveal how, for her, declarative knowledge of target forms can be automatized with practice over time (DeKeyser, 2014), and that extensive listening is an important part of this learning process. As she says:

When I speak, all the rules are there in my mind. I even visualize the three ways of saying the third person singular, /s/, /z/ and /iz/. For example, I visualize the word 'watch' and the sound /t $\mathrm{g} /$ to articulate it. It takes time at the beginning, but it becomes more automatic with time. I watch English movies and imitate the ways people speak as well. (Cuc)

Both Cuc and Huong saw extensive listening and attending to language features in the input as instrumental in helping them develop automaticity in language use. In Cuc's case, it also led to a moderately high level of accuracy in producing $3 \mathrm{SG}-S$.

Another student, Quynh, who works part-time at a shop selling ice-cream for foreign tourists, sees ending sounds as important for comprehensibility and sounding "natural" in communication: 
The most important thing for me when speaking in English is how to make the listener understand what we want to say to them. For the ending sounds $(3 S G-s) I$ always try to pronounce them to sound more natural but to be honest I cannot always remember this. (Quynh)

However, Quynh omitted 3SG-S in $95 \%$ of obligatory contexts. This suggests that the attentional demands of real-time communication prevent Quynh from attending to $3 \mathrm{SG}-S$ sufficiently to proceduralize her declarative knowledge of this form.

Surprisingly, the influence of the L1 was not a pertinent factor that students mentioned in accounting for omission of $3 \mathrm{SG}-s$. In all cases, the factor they repeatedly mentioned was the need to communicate smoothly which reduced their ability to also attend to accuracy. However, some students exhibited a strong orientation to accuracy. Hong, for example, used be copula correctly in $100 \%$ of cases. In the interview, she emphasized the importance of pronouncing inflectional morphemes, which she associated with native-like pronunciation. She said she was determined to work hard on inflectional morphemes, or what she and other students called "ending sounds", to make herself "easiest-to-listen-to". For her, accuracy is commensurate with comprehensibility and native-like standard pronunciation.

In summary, the interview data provided explanatory insights that highlighted the learners' awareness of the trade-offs they had to make between fluency and accuracy when communicating in English in classroom communication activities and in authentic communication in English beyond the classroom. This has implications for teaching, as discussed next.

\section{Discussion}

The present study set out to explore the production of $3 \mathrm{SG}-S$ and be copula by Vietnamese EFL university students. The results show that the students in the study omitted a large majority of $3 \mathrm{SG}-S$ in obligatory contexts (78.4\% omission), thus substantiating our first hypothesis that this would be the case. The second hypothesis that the learners would be better at performing be copula than $3 \mathrm{SG}-S$ was also confirmed. These results confirm findings from previous studies showing that be copula is acquired well before 3SG- $s$ with L1 child learners of English (e.g., Brown, 1973), English L2 learners (Dulay, \& Burt, 1974; Krashen, 1982; Ionin \& Wexler, 2002) and EFL learners (Helland \& Alvarez, 2007; Hsieh, 2009; Urano, 2008). The learners in the present study were a little older than those studied in other L2 morpheme order studies and appeared to have good metalinguistic knowledge of 3SG- $S$ and be copula. However, the acquisition order still holds for these learners. Although there was not enough data to compare individual students, it was observed that lower proficiency students were more likely to omit the target inflectional morphemes, suggesting the variable of proficiency needs attention in future research.

The high omission of $3 \mathrm{SG}-S$ is likely partially due to the influence of Vietnamese $\mathrm{L} 1$ as an isolating language (Ngo, 2001). Because Vietnamese does not have affixal inflection that marks agreement, Vietnamese L1 learners of English "lack prior knowledge that facilitates generalizations over the third-person singular $-s$ " (Blom et al., 2012, p. 26) and so encounter more difficulty with 3SG-s than other learners of English whose L1s are rich in inflection (McDonald, 2000; Siemund \& Lechner, 2015). The findings echo 
research on English learners whose L1 Chinese is an isolating language and who omit $3 \mathrm{SG}-S$ at a greater rate than be copula. (Hsieh, 2009; Jia \& Fuse, 2007; Lardiere, 1999).

In the current study, the congruency between L1 Vietnamese and English in the construction of be copula facilitated its use. While the learners frequently omitted $3 \mathrm{SG}-S$, when they did produce it, they rarely produced it incorrectly, and they never used the finite forms in non-finite contexts. This further suggests that the learners possess a mechanism to monitor their production of functional features, thus supporting the Missing Surface Inflection Hypothesis (Haznedar \& Schwartz, 1997; Ionin \&Wexler, 2002; Prévost \& White, 2000). EFL research (e.g., Hsieh, 2009) also attributes the challenge with 3SG-s to the 'mapping' problem between 'abstract features' such as tense, person and number and surface forms in production (Prévost \& White, 2000, p.127). The low communicative value of $3 \mathrm{SG}-S$ and the need to produce it in a communicative task which adds communicative pressure both intensify this mapping issue (Goldschneider \& DeKeyser, 2001). Thus, for the Vietnamese students in this study, even though they would have been explicitly taught $3 \mathrm{SG}-s$ throughout their secondary and high school education, access to $3 \mathrm{SG}-S$ is 'blocked' during the communication processes.

While other uses of $3 \mathrm{SG}-s$, exclusive of omission, were not common in the data, a sub-group of the students repeatedly used present participles rather than finite forms. The present participle is one of the first grammatical morphemes both English L1 and L2 learners acquire (Brown, 1973; Burt \& Dulay, 1974; Krashen, 1982). Since this sub-group generally had lower proficiency, this tendency suggests that they were at an earlier developmental stage (Pienemann, 2005) and so had more difficulty 'mapping' abstract features onto surface forms than the higher proficiency students. Following this line of argument, these students are not yet developmentally ready to acquire the finite form of $3 \mathrm{SG}-S$.

The study also found that be copula as a suppletive form was produced more consistently in obligatory contexts than $3 \mathrm{SG}-s$. More accurate use of $b e$ copula could be attributable in part to transfer from L1 Vietnamese since in Vietnamese be copula is absent when followed by an adjective, which functions as a stative verb (Dam, 2006) as in the sentence 'Cô ấy đẹp' (Cô ây: She; đẹp: beautiful) [She is beautiful]. However, the Vietnamese be copula 'là' is obligatory when preceding a noun phrase, as in the sentence, 'Cô ấy là một giáo viên trẻ' (Cô ây: She; là: is; một giáo viên trẻ: a young teacher) [She is a young teacher]. Further analysis shows that most missing be copula cases are related to the latter form. This points to the influence of L1 Vietnamese on the acquisition of be copula by Vietnamese EFL learners. Other research (Hsieh, 2009; Jia and Fuse, 2007; Lardiere, 1999) similarly found some positive transfer from L1 Chinese when learners produced be copula more accurately than $3 \mathrm{SG}-s$. These findings support the claim that better use of be copula is due to "the presence of a corresponding functional category in the L2 grammar (Ionin \& Wexler, 2002, p. 108).

Another explanation is that frequent omission of $3 \mathrm{SG}-s$ is attributable to learners reducing the 3SG-S morpheme due to its "word-final position" (Ionin \& Wexler, 2002, p. 108). To test this hypothesis, we carried out an additional analysis to compare the learners' production of 3SG-s with that of irregular forms of 'have' and 'do'. As can be seen in Table 5, the rate of omission for the irregular forms was $43.5 \%$, a lower proportion than that of 3SG- $s$ (78.4\% omission, see Table 2). Also, 'have' (29.3\% omission) seemed far easier than 'do' (64.3\% omission). 
Table 5

Use of 'have' and 'do'

\begin{tabular}{lccc}
\hline & Uninflected forms & Inflected forms & Total obligatory contexts \\
& $n(\%)$ & $n(\%)$ & $n$ \\
\hline Do/does & $18(64.3)$ & $10(35.7)$ & 28 \\
\hline Have/has & $12(29.3)$ & $29(70.7)$ & 41 \\
\hline Total & $30(43.5)$ & $39(56.5)$ & 69 \\
\hline
\end{tabular}

These findings of greater accuracy with the use of irregular forms than $3 \mathrm{SG}-S$ contrasts with findings from Ionin and Wexler (2002), who found similar rates of omission for both $-74 \%$ and $78 \%$, respectively. Ionin and Wexler (2002) explain that omission of $3 \mathrm{SG}-S$ is not of a purely phonological nature (p. 109) because they found no occurrence of 'ha' or sa' in their study. They argued that if omission of $3 \mathrm{SG}-S$ was due to the learners reducing the final morpheme of a word, then they would find more consistent production of irregular forms. However, they found similar rates of omission of $3 \mathrm{SG}-s$ (regular verbs) (78\%) and irregular verbs (74\%) as indicated above. Ionin and Wexler (2002) argue that "agreement morphology on thematic verbs does not reflect a particular difficulty with affixation. Rather, L2 learners have a particular difficulty using inflection on thematic verbs" (Ionin \& Wexler, 2002, p. 110). The present study also found no occurrence of 'ha', and students were more accurate with irregular forms than the $3 \mathrm{SG}-s$ forms of regular verbs. We interpret the current data as suggesting that for Vietnamese EFL learners, omission of $3 \mathrm{SG}-S$ is related to difficulty with both affixation and inflection. Vietnamese L1 as an isolating language (Ngo, 2001) might have better facilitated the production of 'has' and 'does' as suppletive forms and as stand-alone words than that of 3SG- $S$ as an affixive form. Affixation is lacking in Vietnamese L1 and thus is more challenging for students to 'map' abstract features such as tense and number onto surface forms (Prévost \& White, 2000, p. 127), especially under communicative pressure.

Interviews with the students further point to how pressure to communicate and achieve comprehensibility contributed to the issue of mapping. As the learners saw it, omission was a consequence of the need to communicate effectively, and so to prioritize fluency over accuracy. The students cared about making themselves understood and desired to align socially with their interlocutor. This is an affordance that teachers can build on in their use of communicative tasks. But it is also a caution about the need to ensure that fluency practice gives learners opportunities to refine what it is that they are practising. One option would be for teachers to use the same or similar tasks (task repetition) and to alternate a focus on fluency or accuracy (see Bygate, 2018).

Over the three weeks in which the learners performed the tasks, we found no improvement in their use of $3 \mathrm{SG}-s$, even though all the tasks were focused tasks that were designed to require the use of this form. It may be that what was lacking was deliberate awareness-raising of the target feature early in the sequence of tasks. Without this, the tasks just provided repeated opportunities for the learners to commit the same errors (Thai \& Boers, 2016). As Han (2002, p. 18) notes, "repeated practice without cognition leads only to rapidness; practice with cognition leads to improvement”. From a Skills Acquisition perspective (DeKeyser, 2014) practice is helpful, especially for difficult constructions that are not present in the L1, like $3 \mathrm{SG}-S$ for Vietnamese EFL learners. Within a task-based teaching framework, consciousness-raising does not require a return to lessons dominated 
by pre-teaching of discrete grammar points (Willis \& Willis, 2007). Given the role of input in language learning (Gass 1997), which students in the present study acknowledged, integrating a listening component into the speaking course is theoretically and pedagogically justified, and espoused within task-based language teaching (Ellis, 2018). In such an integrated approach, listening texts and associated activities could be used to draw attention to $3 \mathrm{SG}-S$ or be copula. Activities that are manipulated to include the later acquired morphemes could also help students better perceive it in the input. This could then help raise their awareness of the target form and possibly allow them to better notice it in normal speech. Other options include getting selected students to perform the task again in front of the class and then discussing aspects of the performance (Nguyen \& Newton, 2020), and post-task activities in which errors and language forms are discussed. This could involve students analyzing their performance transcripts (Skehan, 2014) or teachers providing post-task corrective feedback or conducting explicit teaching of the target forms as necessary (Willis \& Willis, 2007).

\section{Conclusion}

The study involved two main innovations. First, data was collected from a series of pedagogic task performances over three weeks in the classroom context rather than oneshot data collection, thus providing a rich data set for analysis. Second, selected learners were interviewed to obtain their insights into their use or non-use of $3 \mathrm{SG}-S$. The use of student self-report data in studies on this topic is rare. Overall, findings from the study provide insights into the use of $3 \mathrm{SG}-S$ and be copula by Vietnamese EFL learners when performing classroom communication tasks. Students omitted the inflectional $3 \mathrm{SG}-S$ morpheme in most obligatory contexts but were more accurate with be copula. This finding lends support to the Missing Surface Inflection Hypothesis (Haznedar \& Schwartz, 1997; Prévost \& White, 2000). From the perspective of the students, it was the pressure of faceto-face communication in English that led them to forego devoting attention to producing these forms. The role of learners as agentive players warrants further attention in SLA research of this kind. Future research could also explore the production of $3 \mathrm{SG}-S$ in tandem with the plural form- $s$ of nouns, or the effects of different focus-on-form treatments such as those discussed above on the production of $3 \mathrm{SG}-s$. Finally, the findings reported in this study show that learner proficiency is an important individual variable to consider in future studies, preferably with a larger sample of data.

Correspondence should be addressed to Bao Trang Thi Nguyen.

Email: ntbtrang@hueuni.edu.vn

\section{Note}

${ }^{1}$ This pre-course test is commonly used in the current Vietnamese educational context. It uses a 10-point proficiency scale. The scores of the participating learners ranged from 6.3 to $9.7(\mathrm{M}=7.8, \mathrm{SD}=0.98)$. 


\section{References}

Blom, E., Paradis, J., \& Duncan, T. S. (2012). Effects of input properties, vocabulary size, and L1 on the development of third person singular $-s$ in child L2 English. Language Learning, 62(3), 965-994. https://doi.org/10.1111/j.1467-9922.2012.00715.x

Brown, R. A. (1973). First language: The early stages. Harvard University Press. Bryman, A. (2008). Social research methods (3rd ed.). Oxford University Press. Bybee, J. (2010). Language, usage and cognition. Cambridge University Press. Bygate, M. (Ed.) (2018). Learning language through task repetition. John Benjamins.

Casanave, C. P. (2010). Distancing: From real life experiences to final research reprort in qualitative inquiry with multilingual participants. In the 2010 Symposium on Second Language Writing, University of Murcia, Spain.

Collins, L. (20005). Accessing second language learners' understanding of temporal morphology. Language Awareness, 14(4), 207.220. https://doi.org/10.1080/09658410508668837

Dam, P. (2006). Analyzing some persistent errors in English made by Vietnamese speakers. In P. Dam \& M. Cowart (eds.), Critical issues in the education of English language learners (pp. 186-196). CANH NAM Publishers, Inc.

DeKeyser, R. (1998). Beyond focus on form: Cognitive perspectives on learning and practicing second language grammar. In C. Doughty \& J. Williams (Eds.), Focus on form in classroom second language acquisition (pp. 42-63). Cambridge University Press.

DeKeyser, R. M. (2014). Skill acquisition theory. In B. VanPatten \& J. Williams (Eds.), Theories in second language acquisition: An introduction (2nd ed., pp. 94112). Routledge.

Duff, P. A. (1986). Another look at interlanguage talk: Taking task to task. In R. R. Day (Ed.), Talking to learn: Conversation in second language acquisition (pp. 147-181). Newbury House.

Dulay, H., \& Burt, M. (1974). Natural sequences in child second language acquisition. Language Learning, 24, 37-53. https://doi.org/10.1111/j.1467-1770.1974.tb00234.x

Ellis, N., \& Sagarra, N. (2010). The bounds of adult language acquisition: Blocking and learned attention. Studies in Second Language Acquisition, 32, 553- 580. https://doi.org/10.1017/S0272263110000264

Ellis, R. (2003). Task-based language learning and teaching. Oxford University Press.

Ellis, R., \& Shintani, N. (2013). Exploring language pedagogy through second language acquisition research. Routledge.

Freeman, D. (1975). The acquisition of grammatical morphemes by adult ESL learners.TESOL Quarterly, 9(4), 409-419. https://doi.org/10.2307/3585625

Fromkin, V., \& Rodman, R. (1998). An Introduction to language (6 $6^{\text {th }}$ ed.). Harcourt Brace College.

Gass, S. (1997). Input, interaction and the second language learner. Erlbaum.

Goldschneider, J. M., \& DeKeyser, R. M. (2001). Explaining the "natural order of L2 morpheme acquisition" in English: A meta-analysis of multiple determinants. Language Learning, 51(1), 1-50. https://doi.org/10.1111/1467-9922.00147 
Han, Z. H. (2002). Rethinking the role of corrective feedback in communicative language teaching. RELC Journal, 33(1), 1-34. https://doi.org/10.1177/003368820203300101

Haznedar, B., \& Schwartz, B.D. (1997). Are there optional infinitives in child L2 acquisition? In E. Hughes, M, Hughes, \& A. Greenhill (eds.), Proceedings of the $21^{\text {st }}$ annual Boston university conference on language development (pp. 257-68). Cascadilla Press.

Helland, C. \& Alvarez, E. (2007). The optional infinitive stage and child L2 English. Barcelona English Language and Literature Studies, 16, 1-14.

Hsieh, F.-T. (2009). The acquisition of English agreement/tense morphology and copula be by L1-Chinese-speaking learners. Paper presented at the Lancaster University Postgraduate Conference in Linguistics and Language Teaching (pp. 46-59). Lancaster University.

Ionin, T., \& Wexler, K. (2002). Why is 'is' easier than '-s'?: Aquisition of tense/agreement morphology by child second language learners of English. Second Language Research, 18(2), 95-136. https://doi.org/10.1191/0267658302sr195oa

Jia, G., \& Fuse, A. (2007). Acquisition of English grammatical morphology by native Mandarin-speaking children and adolescents: Age-related differences. Journal of Speech, Language, and Hearing Research, 50, 1280-1299. https://doi.org/10.1044/1092-4388(2007/090)

Jiang, N., Novokshanova, E., Masuda, K., \& Wang, X. (2011). Morphological congruency and the acquisition of L2 morphemes. Language Learning, 61(3), 940-967. https://doi.org/10.1111/j.1467-9922.2010.00627.x

Kelly, N. (2017). The acquisition of the third person singular [-s]: A case study of language-minority children attending an Irish primary school. English Linguistics Research, 6(1), 1-13. https://doi.org/10.5430/elr.v6n1p1

Krashen, S. (1982). Principles and practice in second language acquisition. Pergamon Press.

Lardiere, D. (1999). Suppletive agreement in second language acquisition. In Greenhill, A., Littlefield, H. and Tano, C.(Eds.), Proceedings of the 23rd Annual Boston University Conference on Language Development. Cascadilla Press.

Lardiere, D. (2000). Mapping features to forms in second language acquisition. In J. Archibald (ed.), Second language acquisition and linguistic theory (pp. 102-29). Blackwell.

Leonard, L., Fey, M., Deevy, P., \& Bredin-oja, S. L. (2015). Input sources of third person singular $-s$ inconsistency in children with and without specific language impairment. Journal of Child Language, 42(4), 1-35. https://doi.org/10.1017/S0305000914000397

Levelt, C., Schiller, N., \& Levelt, W. (2000). The acquisition of syllable types. Language Acquisition, 8, 237-264. https://doi.org/10.1207/S15327817LA0803_2

Li, C., \& Gao, X. (2017). Bridging "what I said" and "why I said it": the role of metapragmatic awareness in L2 request performance. Language Awareness, 26(3), 170-190. https://doi.org/10.1080/09658416.2017.1387135

Lyster, R., Saito, K., \& Sato, M. (2013). Oral corrective feedback in second language classrooms. Language Teaching, 46(1), 1-40. https://doi.org/10.1017/S0261444812000365 
McDonald, J. (2000). Grammaticality judgments in a second language: Influences of age of acquisition and native language. Applied Psycholinguistics, 21(3), 395-423. https://doi.org/10.1017/S0142716400003064

Miles, M. B., \& Huberman, A. M. (1994). Qualitative data analysis: A sourcebook of new methods. SAGE.

Muftah, M., \& Rafik-Galea, S. (2013). Error analysis of present simple tense in the interlanguage of adult Arab English language learners. English Language Teaching, $6(2), 146-154$.

Ngo, B. N. (2001). The Vietnamese language learning framework. Part One: Linguistics. Journal of Southeast Language Teaching, 10, 1-23.

Nguyen, B.T.T., \& Newton, J. (2020). Learner proficiency and EFL learning through task rehearsal and performance. Language Teaching Research, 24(5), 588-615. https://doi.org/10.1177/1362168818819021

Paradis, J. (2005). Grammatical morphology in children learning English as a second language: Implications of similarities with specific language impairment. Language, Speech and Hearing Services in the Schools, 36, 172-187.

https://doi.org/10.1044/0161-1461(2005/019)

Paradis, J. (2011). Individual differences in child English second language acquisition: Comparing child-internal and child-external factors. Linguistic approaches to bilingualism, 1, 213-237. https://doi.org/10.1075/lab.1.3.01par

Paradis, J., Rice, M., Crago, M., \& Marquis, J. (2008). The acquisition of tense in English: Distinguishing child second language from first language and specific language impairment. Applied Psycholinguistics, 29, 689-722. https://doi.org/10.1017/S0142716408080296

Prévost, P., \& White, L. (2000). Missing surface inflection or impairment in second language acquisition? Evidence from tense and agreement. Second Language Research, 16, 103-33. https://doi.org/10.1191/026765800677556046

Rice, M.L. \& Wexler, K. (1996). Toward tense as a clinical marker of specific language impairment in English-speaking children. Journal of Speech and Hearing Research, 39, 1239-57. https://doi.org/10.1044/jshr.3906.1239

Rogers, J., Révész, A., \& Rebuschat, P. (2016). Implicit and explicit knowledge of inflectional morphology. Applied Psycholinguistics, 37(4), 781 - 812. https://doi.org/10.1017/S0142716415000247

Schmidt, R. (2001). Attention. In P. Robinson (Ed.), Cognition and second language instruction (pp. 3-32). Cambridge University Press.

Siemund, P., \& Lechner, S. (2015). 'Transfer effects in the acquisition of English as an additional language by bilingual children in Germany,' In Hagen Peukert (Ed.), Transfer effects in multilingual language development (pp.1-14). Benjamins.

Silverman, D. (2010). Doing qualitative research (3rd ed.). SAGE.

Skehan, P. (2014). Before and after the task: Potential research-based contributions. OnTask, 4(1), 4-10. http://www.tblsig.org/wpcontent/uploads/2014/05/OnTaskVol4Iss1May2014.pdf

Skehan, P. (2015). Limited attention capacity and cognition: Two hypotheses regarding second language performance on tasks. In M. Bygate (Ed.), Domains and directions 
in the development of TBLT: A decade of plenaries from the international conference (pp. 123-156). John Benjamins.

Thai, C., \& Boers, F. (2016). Repeating a monologue under increasing time pressure: effects on fluency, complexity, and accuracy. TESOL Quarterly, 50(2), 369-393. https://doi.org/10.1002/tesq.232

Urano, K. (2008). Potential causes of errors in subject-verb agreement in L2 English. Bulletin of the Chubu English Language Education Society, 37, 41-48.

Vainikka, A. \& Young-Scholten, M. (1996). 'The early stage of adult L2 syntax: additional evidence from Romance speakers'. Second Language Research, 12, 140-176. https://www.jstor.org/stable/43104510

Wee, R., Sim, J., \& Jusoff, K. (2010). Verb-form errors in EAP writing. Educational Research and Reviews, 5(1), 016-023. https://doi.org/10.5897/ERR.9000408

Wexler, K. (1994). Optional Infinitives, head movement and the economy of derivations. In D. Lightfoot, \& N. Hornstein (eds.) Verb movement. Cambridge University Press.

Willis, D., \& Willis, J. (2007). Doing task-based teaching. Oxford University Press.

Zobl, H., \& Liceras, J. (1994). Functional categories and acquisition orders. Language Learning, 44, 159-80. https://doi.org/10.1111/j.1467-1770.1994.tb01452.x 


\section{Appendix}

Instruction for all tasks: You have 10 minutes to prepare individually and after that you take turns to talk to your friend.

TASK 1. Work in pairs, talking about the job of a person you know. Describe his/her job, and what he/she does every day as part of his/her job.

TASK 2. Work in pairs, talking about one person you adore and why.

TASK 3. Who is your everyday hero? Why?

TASK 4. Work in pairs, talking about what one of your best friends does in his or her free time.

TASK 5. Work in pairs, asking each other what you do every day/ every week to improve English (To improve Reading, Listening, Writing, Speaking, Grammar and to enrich Vocabulary). 